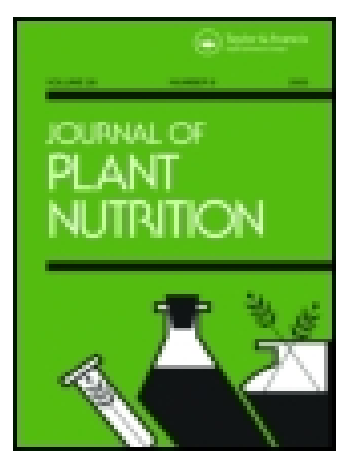

Journal of Plant Nutrition

ISSN: 0190-4167 (Print) 1532-4087 (Online) Journal homepage: http://www.tandfonline.com/loi/lpla20

\title{
Effects Of Selenium as a Beneficial Element on Growth and Photosynthetic Attributes of Greenhouse Cucumber
}

\section{Maryam Haghighi, Atena Sheibanirad \& Mohammad Pessarakli}

To cite this article: Maryam Haghighi, Atena Sheibanirad \& Mohammad Pessarakli (2015): Effects Of Selenium as a Beneficial Element on Growth and Photosynthetic Attributes of Greenhouse Cucumber, Journal of Plant Nutrition, DOI: 10.1080/01904167.2015.1109116

To link to this article: http://dx.doi.org/10.1080/01904167.2015.1109116

Accepted author version posted online: 09

Nov 2015.

Published online: 09 Nov 2015.

Submit your article to this journal $₫$

Џ Article views: 45

Q View related articles $\longleftarrow$

View Crossmark data \lceil 


\title{
ACCEPTED MANUSCRIPT
}

Effects Of Selenium As A Beneficial Element On Growth And Photosynthetic Attributes Of

Greenhouse Cucumber

\author{
Maryam Haghighi ${ }^{1}$, Atena Sheibanirad ${ }^{1}$ and Mohammad Pessarakli ${ }^{2, *}$ \\ ${ }^{1}$ Department of Horticultural Sciences, Isfahan University of Technology, Isfahan, Iran \\ ${ }^{2}$ School of Plant Sciences, The University of Arizona, Tucson, AZ 85721, USA \\ *Address Correspondence to Mohammad Pessarakli : pessarak@email.arizona.edu
}

\begin{abstract}
Selenium (Se) is an essential element for human and livestock with antioxidant and anticancer characteristics. Although Se is not an essential element for plants, it has been reported that it can improve plant growth. This experiment was conducted at the Isfahan University of Technology in winter 2010. The experiment was factorial based on a completely randomized design (CRD) with 4 replications. Se was added to nutrient solution in 4 concentrations 2 , 4, and $6 \mathrm{mg} / \mathrm{l}$ sodium selenite $\left(\mathrm{Na}_{2} \mathrm{SeO}_{3}\right)$. Root volume, fresh and dry weights of shoots and roots, number and weight of fruits, chlorophyll content and photosynthesis traits (photosynthesis rate, stomata internal carbon dioxide $\left(\mathrm{CO}_{2}\right)$ concentration, stomata conductance) were measured. Results showed that Se increased root dry weight. Fresh and dry weights of shoot increased in the $2 \mathrm{mg} / \mathrm{l} \mathrm{Se}$ treatment and decreased at the higher level of Se. Chlorophyll content and photosynthesis rate were not affected by Se. Stomata internal $\mathrm{CO}_{2}$ concentration and stomata conductance decreased by Se addition. Overall, Se at $2 \mathrm{mg} / \mathrm{l}$ application rate was effective in some physiological characteristics of cucumber.
\end{abstract}

\section{Keywords}




\section{ACCEPTED MANUSCRIPT}

Selenium, Hydroponics, Cucumber, Stomata internal $\mathrm{CO}_{2}$, Stomata conductance

\section{ABBREVIATIONS}

$\mathrm{Se}=$ Selenium, $\mathrm{Se} 0=\quad 0, \mathrm{Se} 1=\quad 2, \mathrm{Se}=\quad 4, \mathrm{Se} 3=6 \mathrm{mgL}^{-1} \mathrm{Se}$ 


\section{ACCEPTED MANUSCRIPT}

\section{INTRODUCTION}

Selenium (Se) is an essential micro element with antioxidant, anti-cancer and antivirus characteristics for human and animal health. There is no evidence for its necessity for plant growth (Lyons et al., 2003). However, some research has shown that applying Se fertilizer to the soil increased plant growth and yield (Helal Ragab et al., 2010). Scientists have paid special attention to Se because of its protective role in chemical sensitive reactions against oxidative damages in human bodies. Se supports the group of enzymes coordinated with vitamin E against free radicals and oxidative damages to the cells and body tissues. For example, when immune system destroys foreign raiders some oxidase compounds are produced, then Se related enzymes change these products to harmless compounds for human bodies. Moreover, Se is involved in the thyroid activity--the gland which regulates metabolism rate. Also, in low blood level, Se was related to some heart disease and some kind of cancer developments (Simojoki et al., 2003). Se was found in meat, vegetable and those cereals grown in Se rich soils (Simojoki et al., 2003). Total amount of Se in most soils is often about 0.1 to $2 \mathrm{mg} \mathrm{kg}^{-1}$ and averaged about $0.3 \mathrm{mg} \mathrm{kg}^{-1}$. In the soil, Se has various forms, including elemental $\mathrm{Se}$, selenide $\left(\mathrm{Se}^{-2}\right)$, selenite $\left(\mathrm{SeO}_{3}{ }^{2-}\right)$, selenate $\left(\mathrm{SeO}_{4}{ }^{2-}\right)$ and organic Se. The most important parameters which control Se solubility and its chemical form in the soil are $\mathrm{pH}$ and redox potential (Geoffroy et al., 2007). The relationship between soil $\mathrm{pH}$ and the amount of absorbed Se by plants showed increased soil $\mathrm{pH}$ increased $\mathrm{Se}$ absorption (Malakooti and Tehrani, 2005). Plants show different physiological reactions to Se levels, some species accumulate it, but some others are sensitive to it and Se is a toxic element to them (Smith and Watkinson, 1984). Most of the plants have some amount of Se which is often about $25 \mathrm{mg} \mathrm{kg}^{-1}$ and rarely increased up to $100 \mathrm{mg} \mathrm{kg}^{-1}$. Some plants have the ability to 


\section{ACCEPTED MANUSCRIPT}

accumulate Se to a level that is toxic to human and livestock. Although Se is not an essential element for plant growth, in some cases in order to have it sufficient for human and livestock food chain, it is added to the soil. It should be noted that the allowable amount of Se is relatively limited (Kabata-Pendis and Alina, 2011). Recently, because of the importance of Se in food chain, scientists have paid more attention to its contents in crop plants. In the recent years, it has been shown that antioxidant contents and abiotic stress resistance in some plants have increased with Se addition to soils (Hanson et al., 2004; Lyons et al., 2008). Using Se fertilizer under oxidative stress on broccoli reduced (deoxyribonucleic acid) DNA rupturing and breaking (Arvy et al., 1995). Drought stress damages with applying Se decreased (Hasanuzzaman and Fujita, 2011). In tomato plants planted in soil with the high levels of mercury ( $\mathrm{Hg}), \mathrm{Hg}$ accumulation was prevented by Se application (Kopsell et al., 2000). By Se application on cucumbers under cold stress, antioxidant activity increased and lipid peroxidation decreased (Liu et al., 2009). There are not sufficient experiments conducted on the proper amount of Se and its effect on plant growth and physiology. In this study, different levels of Se on cucumbers growth and physiology were evaluated using a hydroponic system.

\section{MATERIALS AND METHODS}

This experiment was conducted in the greenhouse of the Isfahan University of Technology in winter 2010. A factorial experiment, arranged in a completely randomized design with 4 replicates and 4 levels of $\mathrm{Se}, \mathrm{Se} 0=0, \mathrm{Se} 1=2, \mathrm{Se} 2=4$ and $\mathrm{Se} 3=6 \mathrm{mgL}^{-1}$ was used in this study. The source of the $\mathrm{Se}$ was sodium selenite $\left(\mathrm{Na}_{2} \mathrm{SeO}_{3}\right)$ and was added to all the 16 plant growth containers. 


\section{ACCEPTED MANUSCRIPT}

The cucumber variety used in this study was Cucumis sativus cv. 4200 that was grown in peat substrate. The greenhouse day and night average temperatures were $25 / 17{ }^{\circ} \mathrm{C}$. Seedlings after 6 weeks growing from the seeds that were at the 2-leaves stage of growth were moved from peat substrate, their roots were thoroughly washed and they were transferred to the nutrient solution. At the first week of the experiment, seedlings were exposed to a half nutrient solution concentration and then with complete nutrient solution and in the $10^{\text {th }}$ day after transplanting Se treatments were applied to the growth containers. During the experimental period, nutrient solution levels on each plant container were checked daily. The composition of the nutrient solution in $\mathrm{mg} \mathrm{L}^{-1}$ is given in Table 1 (Jones, 1930).

After 5 weeks growth in the nutrient solution, the plants were harvested and measurements were made. In the last week of the experiment, the leaves chlorophyll contents were measured using chlorophyll meter (SPAD-502, Minolta Corp., Ramsey, NJ, USA). Then, in sixth week photosynthesis rate $\left(\mu \mathrm{mol} \mathrm{m} \mathrm{m}^{-2} \mathrm{~s}^{-1}\right)$, stomata conductance $\left(\mathrm{g}_{\mathrm{c}}\right)\left(\mathrm{mol} \mathrm{m} \mathrm{m}^{-2} \mathrm{~s}^{-1}\right)$ and stomata internal carbon dioxide $\left(\mathrm{CO}_{2}\right)(\mathrm{Ci})$ content $(\mu \mathrm{mol})$ were measured using photosynthesis meter (Li-Cor, Li-3000, USA). Root volume was measured using the method of changes in the water volume. Shoots were excised from the roots using a steel blade, then fresh weights of the roots and the shoots were measured. Then, all samples were oven dried at $70^{\circ} \mathrm{C}$ for 48 hours and the dry weights were measured. Data were analyzed using Statistix 8 (Tallahassee FL, USA). All data were subjected to one-way analysis of variance (ANOVA) and the means were compared for significance by the least significant difference (LSD) test at $\mathrm{P}<0.05$. All figures were drawn using Microsoft Office Excel 2007. 


\section{ACCEPTED MANUSCRIPT}

\section{RESULTS}

Effects of Different Levels of Se on Root and Shoot Fresh and Dry Weights, Root Volume, Numbers and Weights of the Cucumbers

As shown in Table 2, a significant reduction was seen in root fresh weight under 2 and $6 \mathrm{mgL}^{-1}$ Se. Shoot fresh weight in the $2 \mathrm{mgL}^{-1}$ Se treatment was $42 \%$ more than that of the control (Table 2). However, with increasing Se concentration to 4 and $6 \mathrm{mgL}^{-1}$, fresh weight decreased $35 \%$ and 50\%, respectively (Table 2). Applying higher levels of Se significantly increased root dry weight (Table 2). Compared Se1 treatment with $\mathrm{Se} 0$, no significant difference was observed. However, by increasing Se concentration shoot dry weight significantly decreased (Table 2). Compared control treatment with Se 3, the lowest shoot dry weight with 53\% reduction was observed in Se 3 treatment. Root volume increased in Se1, but by increasing Se concentration it was significantly decreased in $\mathrm{Se} 2$ and $\mathrm{Se} 3$ treatments (Table 2). Root volume decreased $31 \%$ and $29 \%$, respectively, in the 4 and $6 \mathrm{mgL}^{-1}$ Se treatments compared to the $2 \mathrm{mgL}^{-1}$ treatment (Table 2). Se had no significant effects on fruit numbers and weights (Table 3).

Effects of Different Levels of Se on Chlorophyll and Photosynthesis Changes of the Cucumbers

The effect of photosynthetic parameters indicated that there was no Se effect on photosynthetic rate (Table 4). However, stomata conductance and the internal $\mathrm{CO}_{2}$ concentration of the stomata decreased by increasing $\mathrm{Se}$ levels (Figure. 1). Stomata conductance and internal $\mathrm{CO}_{2}$ concentration of the stomata decreased $56 \%$ and $41 \%$, respectively, in the $6 \mathrm{mgL}^{-1}$ Se treatment 


\section{ACCEPTED MANUSCRIPT}

compared with the control (Figure 2). Chlorophyll content was not affected by the Se treatments (Table 4).

\section{DISCUSSION}

Se, in most cases, depending on its concentration and the plant age, decreased plant growth and biomasses production. However, in some cases, Se improved plant growth (Germ and Joze, 2005; Grant et al., 1998; Kopsell et al., 2000; Pennanen et al., 2001; Simojoki et al., 2003; Shanker et al., 1996; Valkama et al., 2003; White et al., 2004; Xue et al., 2001). Shoot dry weight of sorghum increased significantly by spraying $150 \mathrm{mg} \mathrm{L}^{-1} \mathrm{Se}$ (Prasad et al., 2008). Peas had higher plant height and dry weight in $50 \mathrm{mg}$ Se than other treatments when Se was applied in 0, 25, 50, and $100 \mathrm{mg} \mathrm{L}^{-1}$ (Helal Ragab et al., 2010). Under salinity stress, applying 0, 5, 10, and $20 \mu \mathrm{M}$ Se on cucumbers increased root dry weight up to $94 \%$ in the $10 \mu \mathrm{M}$ treatment (HawrylakNowak, 2009).

In the present study, root fresh weight decreased in the $\mathrm{Se} 1$ and $\mathrm{Se} 3$ treatments. However, by increasing Se concentration, root dry weight increased. Shoot dry and fresh weights increased in the $2 \mathrm{mgL}^{-1}$ Se treatment, but in the higher Se concentration treatments, both fresh and dry weights decreased. In tomato leaves, the interaction of Se in $0,0.5,1$, and 2 ppm levels with MO on photosynthetic pigments indicated no significant effect on shoot dry weight and total plant dry weight, however root dry weight significantly reduced (Khavarinejad et al., 2010). In the present study, different results were observed that might be related to various physiological growth stages and different Se concentrations on different plants that were used. From this study, it was 


\section{ACCEPTED MANUSCRIPT}

concluded that low Se concentration such as $2 \mathrm{mgL}^{-1}$ and lower are more effective for cucumbers growth.

Photosynthetic pigments like chlorophyll and carotenoids are also affected by Se and usually are decreased in high level of Se (Hawrylak-Nowak, 2009; Lefsrud et al., 2006; Padmaja et al., 1990; Valkama et al., 2003; Xue et al., 2001). In ryegrass and white clover, by increasing Se concentration chlorophyll content decreased (Smith and Watkinson, 1984). In coffee and corn, different levels of Se in a form of selenite decreased photosynthetic pigments, including chlorophyll, carotenoids and xanthophylls in coffee and chlorophyll formation rate in corn (Jain and Gadre, 1998; Mazzafer, 1998). In the present study, Se decreased chlorophyll concentration even though this decrease was not significant. The negative effect of Se on porphobilinogen synthesis which is necessary in Sinapis alba L. chlorophyll biosynthesis was probably the reason for the reduction in chlorophyll content (Fargasova et al., 2006). In the young seedlings of Phaseolus vulgaris L. Se treatments caused decreased in chlorophyll levels in both seedling grown under light and dark conditions (Padmaja et al., 1990).

Se by influencing other elements uptake in plants affected photosynthesis and total plant pigments. In cabbage increasing sodium selenate increased leaves magnesium $(\mathrm{Mg})$ content (Kopsell et al., 2000). In Catharanthus roseus L. cell suspension culture, Mg content was not affected by Se treatment (Arvy et al., 1995). Reductions in Se and sulfur level did not affect carotenoid pigments such as lutein and beta carotene (Kopsell et al., 2000). Stomata conductance and internal $\mathrm{CO}_{2}$ concentration of stomata decreased by increasing Se levels and no significant change was observed in the photosynthetic rate. Based on the available information and the cited 


\section{ACCEPTED MANUSCRIPT}

references, there are only a few studies found on the effect of Se on photosynthesis. Therefore, based on the results of the present study, the Se effect on photosynthesis is not related to stomata conductance, since no significant chlorophyll changes in the same direction with photosynthesis were observed. Also, photosynthesis was not influenced by stomata conductivity and stomata internal $\mathrm{CO}_{2}$ reduction. Therefore, more study on the effects of $\mathrm{Se}$ on photosynthesis is recommended.

\section{CONCLUSIONS}

The highest shoot fresh and dry weights and root volume were observed in the $2 \mathrm{mgL}^{-1} \mathrm{Se}$ treatment, however, in the higher concentrations these parameters were decreased. Also stomata conductance and internal $\mathrm{CO}_{2}$ concentration of the stomata reduced in higher Se treatments. Probably, applying $2 \mathrm{mgL}^{-1} \mathrm{Se}$ and lower may have some effects on photosynthesis. Studying lower Se concentrations on photosynthesis for future experiments, and because of its importance and positive effects on human nutrition and its internal levels in plant tissues more studies about this element is recommended. 


\section{ACCEPTED MANUSCRIPT}

\section{REFERENCES}

Arvy, M.P., M. Thiersault, and P. Doireau. 1995. Relationship between selenium, micronutrients, carbohydrates, and alkaloid accumulation in Catharanthus roseous cells. Journal Plant of Nutrition and Soil Science, 18: 1535-1546.

Fargasova, A., Pastierova, J., and K. Svetkova. 2006. Effect of Se-metal pair combinations

$(\mathrm{Cd}, \mathrm{Zn}, \mathrm{Cu}, \mathrm{Pb})$ on photosynthetic pigments production and metal accumulation in Sinapsis alba L. seedlings Plant Soil and Environment, 52: 8-15.

Geoffroy, L., Gilbin, R., Simona, O., Floriani, M., Adam, H., Pradines, C., Cournac, L., and J. Garnier-Laplace. 2007. Effect of selenate on growth and photosynthesis of Chlamydomonas reinhardtii. JAquatic Toxicology, 83, 149-158.

Germ, M. and O. Joze. 2005. Selenium treatment affected respiratory potential in Eruca sativa. Acta Agriculturae Sloven, 85:329-335.

Grant, C.A., Buckley, W.T., Bailey, L.D., and F. Selles. 1998. Cadmium accumulation in crops. Canadian Journal of Plant Science, 78: 1-18.

Hanson, B., lindblom, S.D., Leoffler, M.L., and E.M. Smits. 2004. Selenium protects plants from phloem feeding aphids due to both deterrence and toxicity. New Phytologist, 162(3): $665-662$.

Hasanuzzaman, M. and M. Fujita. 2011. Selenium Pretreatment Upregulates the Antioxidant Defense and Methylglyoxal Detoxification System and Confers Enhanced Tolerance to Drought Stress in Rapeseed Seedlings. Biological Trace Elements Research, 143: 1758-1776. 


\section{ACCEPTED MANUSCRIPT}

Hawrylak-Nowak, B. 2009. Beneficial Effects of Exogenous Selenium in Cucumber Seedlings

Subjected to Salt Stress. Biological Trace Elements Research, 132: 259--269.

Helal Ragab, M., and M.A. Abd El-Fatah. 2010. Protective Role of Selenium on

Development and Physiological Responses of Vicia faba. International Journal of Vegetable Science, 16: 174--183.

Jain, M. and R.P. Gadre. 1998. Inhibition of chlorophyll synthesis and enzymes of nitrogen assimilation by selenite in excised maize leaf segment during greening.Water, Air, and Soil Pollution, 104: 161-166.

Jones, J.B. 1930. Hydroponics: A Practical Guide for the Soilless Grower. Second Edition.

CRC Press. USA, 439p.

Kabata-Pendis, A. and H. Pendias. 2011. Trace elements in soils and plants. $4^{\text {th }}$ ed., CRC

Press, Boka Raton, Florida, USA, pp: 367-380.

Khavarinejad, R., Gushegir, A., and S. Sadatmand. 2010. The interaction effects of selenium and molybdenum on tomato leaves photosynthetic pigments content. International Journal of Plant Production, 17: 14-23.

Kopsell, D.A., Randle, W.M., and H.A. Mills. 2000. Quantitative, chemically specific imaging of selenium nutrient accumulation in leaf tissue of rapid-cycling Brassica oleracea response to increasing sodium selenate concentrations. Journal of Plant Nutrition, and Soil Science 23: 927-935.

Lefsrud, M.G., Kopsella, D.A., Kopsella, D.E., and W.M. Randle. 2006. Kale Carotenoids 


\section{ACCEPTED MANUSCRIPT}

are unaffected, whereas biomass production, element concentrations, and selenium accumulation respond to changes in selenium fertility. Journal of Agriculture and, Food Chemistry, 54: 1764-1771.

Liu, J., Lin, S-H., Xue, P-L., Wang, X-J., and J-G. Bai.2009. Effects of Exogenous Silicon on the Activities of Antioxidant Enzymes and Lipid Peroxidation in Chilling-Stressed Cucumber Leaves. Agricultural Sciences, 8(9): 1075-1086.

Lyons, G.H., Stangoulis, J., and R. Graham. 2003. High-selenium wheat: biofortification for better health. Nutrition Research Review, 16: 45-60.

Lyons, G.H., Genc, Y., Soole, K., Stangoulis, J.C.R., Liu, F., and R.D. Graham. 2008.

Selenium increases seed production in Brassica. Plant and Soil. 318:73-80.

Malakooti, M. and M. Tehrani. 2005. The micro elements effect on increasing and improving agricultural crop quality. Tarbiat Modarres University Press, Tehran, Iran.

Mazzafer, P. 1998. Growth and biochemical alterations in coffee due to selenite toxicity.

Plant and Soil, 201: 189-196.

Padmaja, K., Prasad, D.D., and A.R. Prasad. 1990. Selenium as a novel regulator of porphyrin biosynthesis in germinating seedlings of mungo bean (Phaseolus vulgaris). International Journal of Biochemistry, 22: 441-446.

Pennanen, A., Hartikainen, H., Lukkari, K., and V. Ollilainen. 2001. Acclimation of Lactuca sativa to increased UV irradiation at various selenium levels. Journal of Photosynthesis Research, Abstract of 12 $2^{\text {th }}$ Congress on Photosynthesis. 69: 30.

Prasad, P.V.V., Pisipati, S.R., Mutava, R.N., and M.R. Tuinstra. 2008. Sensitivity of Grain 


\section{ACCEPTED MANUSCRIPT}

Sorghum to High Temperature Stress during Reproductive Development. Crop Science, 48 : 1911--1917.

Shanker, K., Mishra, S., Sirvastava, S., Sirvastava, R., Daas, D., Prakash, S., and M.M.

Sirvastava. 1996. Effect of selenite and selsnate on plant uptake and translocation of mercury by tomato (Lycopersicum esculentum).Plant and Soil, 183: 233-238.

Simojoki, A., Xue, T., Lukkari, K., Pennen, A., and H. Hartikainen. 2003. Allocation of added selenium in lettuce and its impact on roots. Agriculture and Food Science 12: 155-164.

Smith, G.S. and J.H. Watkinson. 1984. Selenium toxicity in perennial ryegrass and white clover. Journal of Phytopathology, 97: 557-564.

Valkama, E., Kivimaenpaa, M., Hartikainen, H., and A. Wulff. 2003. The combined effects of enhanced UV-B radiation and selenium on growth, chlorophyll fluorescence ultrastructure in strawberry (Fragaria ananassa) and barley (Hordeum vulgare) treated in the field.Agriculture and Forest Meteorology, 120: 267-278.

White, P.J., Bowen, H.C., Parmaguru, P., Fritz, M., Spracklen, W.P., Spiby, R.E., Meacham, M.C., Mead, M., Harriman, M., Trueman, L.J., Smith, B.M., Thomas, B., and M.R. Broadley. 2004. Interaction between selenium and sulphur nutrition in Arabidopsisthaliana. Journal of Experimental Botany, 55: 1927-1937.

Xue, T., Hartikianen, H., and V. Piironen. 2001. Antioxidative and growth promoting effect of selenium on senescing lettuce. Plant and Soil, 237: 55-61. 


\section{ACCEPTED MANUSCRIPT}

Table 1. The composition of the nutrient solution.

\begin{tabular}{|c|c|c|}
\hline & $\begin{array}{l}\text { Stock } \\
\text { solution }\end{array}$ & $\begin{array}{l}\text { ml stock } \\
\text { solution / liter }\end{array}$ \\
\hline $2 \mathrm{M} \mathrm{KNO}_{3}$ & $202 \mathrm{~g} / \mathrm{l}$ & 2.5 \\
\hline $\begin{array}{l}2 \mathrm{M} \\
\mathrm{Ca}\left(\mathrm{NO}_{3}\right)_{2} \bullet 4 \mathrm{H}_{2} \mathrm{O}\end{array}$ & $118 \mathrm{~g} / 1$ & 2.5 \\
\hline $\begin{array}{l}\text { Iron (Sprint } 138 \\
\text { iron chelate) }\end{array}$ & $15 \mathrm{~g} / \mathrm{l}$ & 1 \\
\hline $2 \mathrm{M} \mathrm{MgSO} \mathrm{Mg}_{4} \cdot 7 \mathrm{H}_{2} \mathrm{O}$ & $439 \mathrm{~g} / 1$ & 1 \\
\hline $1 \mathrm{M} \mathrm{NH} \mathrm{NO}_{3}$ & $80 \mathrm{~g} / 1$ & 1 \\
\hline $\mathrm{H}_{3} \mathrm{BO}_{3}$ & $2 / 86 \mathrm{~g} / 1$ & 1 \\
\hline $\mathrm{MnCl}_{2} \cdot 4 \mathrm{H}_{2} \mathrm{O}$ & $1 / 81 \mathrm{~g} / 1$ & 1 \\
\hline $\mathrm{ZnSO}_{4} \cdot 7 \mathrm{H}_{2} \mathrm{O}$ & $0.22 \mathrm{~g} / 1$ & 1 \\
\hline $\mathrm{CuSO}_{4}$ & $0.051 \mathrm{~g} / 1$ & 1 \\
\hline $\mathrm{H}_{3} \mathrm{MoO}_{4} \cdot \mathrm{H}_{2} \mathrm{O}$ & $0.09 \mathrm{~g} / 1$ & 1 \\
\hline $\begin{array}{l}1 \mathrm{M} \mathrm{KH} \mathrm{KH}_{4}(\mathrm{pH} \text { to } \\
6.0)\end{array}$ & $136 \mathrm{~g} / 1$ & 0.5 \\
\hline
\end{tabular}


ACCEPTED MANUSCRIPT

15 ACCEPTED MANUSCRIPT 


\section{ACCEPTED MANUSCRIPT}

Table 2. The effect of selenium (Se) on vegetative characteristics of cucumber.

\begin{tabular}{|c|c|c|c|c|c|}
\hline Treatment & $\begin{array}{l}\text { Shoot dry } \\
\text { weight }(\mathrm{g})\end{array}$ & $\begin{array}{l}\text { Root dry } \\
\text { weight }(\mathrm{g})\end{array}$ & $\begin{array}{l}\text { Shoot fresh } \\
\text { weight }(\mathrm{g})\end{array}$ & $\begin{array}{l}\text { Root fresh } \\
\text { weight }(\mathrm{g})\end{array}$ & $\begin{array}{l}\text { Root } \\
\text { volume (ml) }\end{array}$ \\
\hline Se 0 & $1.165 \mathrm{a}$ & $0.238 \mathrm{~b}$ & $13.275 \mathrm{~b}$ & $11.262 \mathrm{a}$ & $11.083 \mathrm{ab}$ \\
\hline Se 1 & $1.758 \mathrm{a}$ & $0.451 \mathrm{a}$ & $18.873 \mathrm{a}$ & $8.573 \mathrm{bc}$ & $12.667 \mathrm{a}$ \\
\hline Se 2 & $1.149 \mathrm{~b}$ & $0.366 \mathrm{a}$ & $12.137 \mathrm{ab}$ & $10.510 \mathrm{ab}$ & $8.667 \mathrm{~b}$ \\
\hline Se 3 & $0.774 \mathrm{~b}$ & $0.441 \mathrm{a}$ & $9.817 \mathrm{c}$ & $6.510 c$ & $8.917 b$ \\
\hline
\end{tabular}




\section{ACCEPTED MANUSCRIPT}

Table 3. The effect of selenium ( $\mathrm{Se}$ ) on reproductive characteristics of cucumber.

\begin{tabular}{lll}
\hline Treatment & Fruit weight $(\mathrm{g})$ & Fruit number \\
\hline Se 0 & $36.55 \mathrm{a}$ & $6.5 \mathrm{a}$ \\
Se 1 & $31.67 \mathrm{a}$ & $5.4 \mathrm{a}$ \\
Se 2 & $33.51 \mathrm{a}$ & $5.8 \mathrm{a}$ \\
Se 3 & $28.14 \mathrm{a}$ & $6.0 \mathrm{a}$ \\
\hline
\end{tabular}

Within each column, means with different letters are significantly different at $\mathrm{P}<0.05$.

Se 0: without Se, Se 1: 2, Se 2: 4, Se 3: $6 \mathrm{mg}^{-1}$ Se. 


\section{ACCEPTED MANUSCRIPT}

Table 4. The effect of selenium (Se) on photosynthetic rate and chlorophyll content of cucumber.

\begin{tabular}{llc}
\hline Treatment & $\begin{array}{l}\text { Photosynthetic } \\
\left.\mathrm{CO}_{2} \mathrm{~m}^{-2} \mathrm{~s}^{-1}\right)\end{array}$ & $\begin{array}{c}(\mu \mathrm{mol} \\
\text { Value })\end{array}$ \\
\hline Se 0 & $3.36 \mathrm{a}$ & $156.85 \mathrm{a}$ \\
Se 1 & $3.68 \mathrm{a}$ & $172.85 \mathrm{a}$ \\
Se 2 & $3.70 \mathrm{a}$ & $150.19 \mathrm{a}$ \\
Se 3 & $3.13 \mathrm{a}$ & $153.08 \mathrm{a}$ \\
\hline Within each column, means with different letters are significantly different at $\mathrm{P}<0.05$.
\end{tabular}




\section{ACCEPTED MANUSCRIPT}

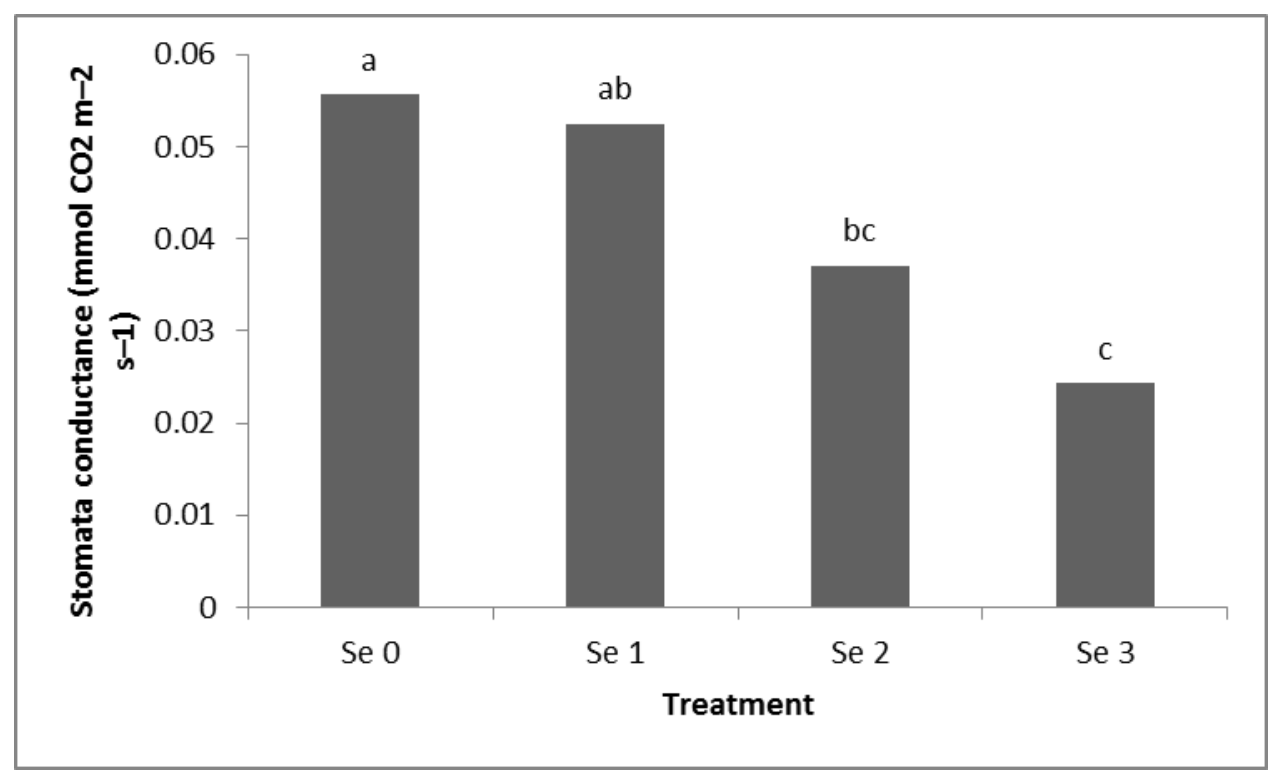

Figure 1. The effect of selenium (Se) on Stomatal conductance. Treatment means with different letters are significantly different at $\mathrm{P}<0.05$. Se 0: without Se, Se 1: 2, Se 2: 4, Se 3: $6 \mathrm{mg}^{-1}$ Se. 


\section{ACCEPTED MANUSCRIPT}

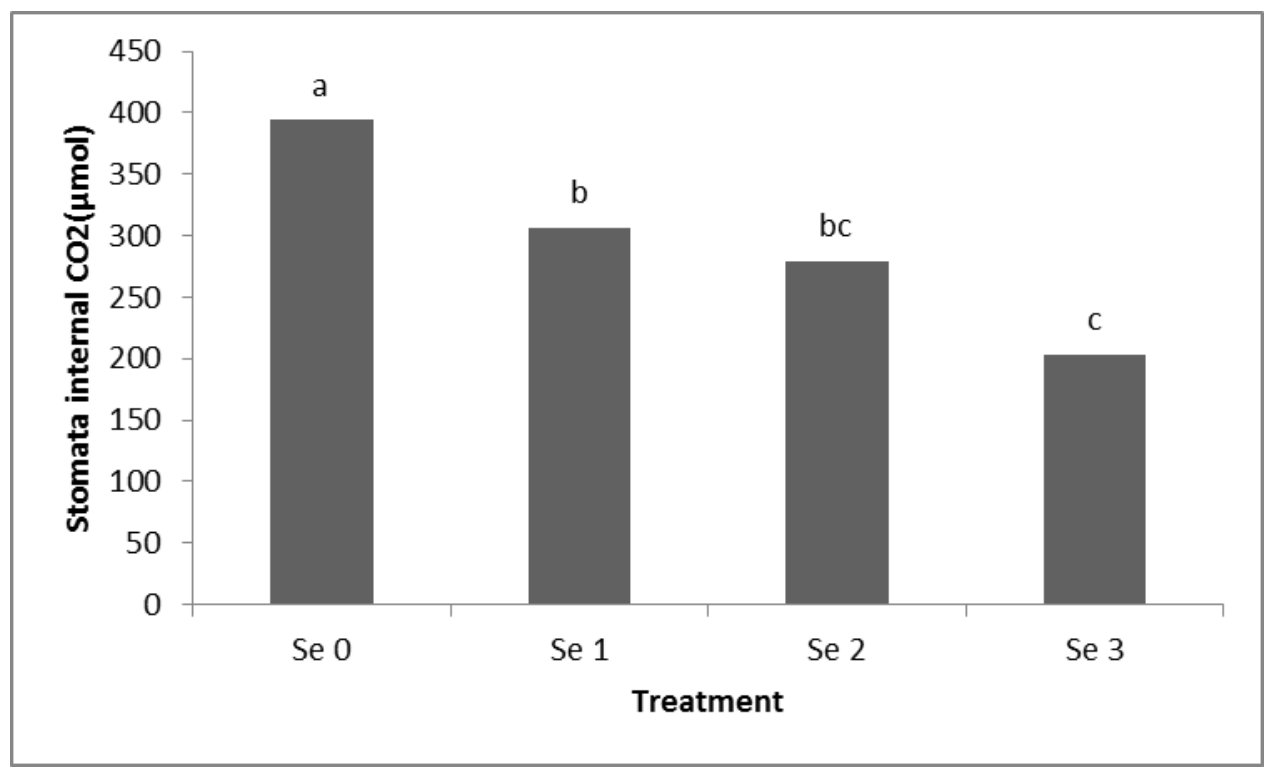

Figure 2. The effect of selenium (Se) on stomata internal $\mathrm{CO}_{2}$ content. Treatment means with different letters are significantly different at $\mathrm{P}<0.05$. Se 0: without Se, Se 1: 2, Se 2: 4, Se 3: 6 $\mathrm{mg} 1^{-1} \mathrm{Se}$. 